Postprint of Renewable Energy Volume 123, August 2018, Pages 541-548

DOI: https://doi.org/10.1016/j.renene.2018.02.004

\title{
INCREASE IN BIOGAS PRODUCTION IN ANAEROBIC SLUDGE DIGESTION BY COMBINING AEROBIC HYDROLYSIS AND ADDITION OF METALLIC WASTES
}

\author{
Silvio Montalvo ${ }^{* a}$, StephaniaVielma $^{a}$, Rafael Borja $^{b}$, César Huiliñir $^{\mathrm{a}}$, Lorna Guerrero $^{\mathrm{c}}$ \\ ${ }^{a}$ Universidad de Santiago de Chile, Av. Lib. Bdo. O`Higgins 3363, Santiago de Chile. Chile \\ ${ }^{\mathrm{b}}$ Instituto de la Grasa, Campus Universitario Pablo de Olavide - Edificio 46, Ctra. de \\ Utrera, km. 1, 41013 Sevilla, España. \\ 'UniversidadTécnica Federico Santa María, Av. España 1680, Valparaíso, Chile \\ *Corresponding author: S. Montalvo (Universidad de Santiago de Chile, Av. Lib. Bdo. \\ O`Higgins 3363, Chile, Santiago de Chile, Chile, E-mail: silvio.montalvo@usach.cl)
}

\begin{abstract}
The objective of this work was to determine the effect of a controlled micro-aeration as a pretreatment or hydrolytic stage of mixed sewage sludge and the incorporation of solid wastes as a source of trace metals in the anaerobic digestion of this pretreated sludge. Three experimental runs were carried out under the same conditions in laboratory-scale anaerobic reactors, to which a previously aerated mixed sludge was added as a substrate and anaerobic sludge as the inoculum. Two anaerobic digesters (blank) were also operated without aerobic pretreatment and without the addition of solid wastes. The aerobic pretreatment was performed with an aeration flow of $0.35 \mathrm{vvm}$, time of 48 hours and temperature of $35{ }^{\circ} \mathrm{C}$. All anaerobic reactors were operated at the mesophilic temperature
\end{abstract}


of $35 \pm 2{ }^{\circ} \mathrm{C}$. Fly ash or Copper mining residues were added to the anaerobic reactors as trace metal supplementation. The aggregated concentrations were $250 \mathrm{mg} . \mathrm{L}^{-1}$ fly ash, 25 mg. $\mathrm{L}^{-1}$ Copper mining residues and $0 \mathrm{mg} / \mathrm{L}$. The blank reactors produced $38 \%$ less methane than those generated in the reactors operating with the pre-aerobic treatment without addition of solid wastes (controls). It was found that the reactors with micro-aerobic pretreated sludge and the addition of fly ash gave the best yields of methane, producing a 201.6\% increase in methane with respect to the blank reactors. On the other hand, the pretreatment of micro-aerobic hydrolysis and the addition of mining residues generated an increase of $185.8 \%$ in methane production compared to the blank reactors.

Key words: anaerobic digestion; copper mining residues; fly ash; methane production; micro-aeration; sewage sludge

\section{INTRODUCTION}

One of the great problems that occur in sewage treatment plants is the enormous amount of sludge that is generated from the primary sedimentation of wastewaters and the production of the waste activated sludge (WAS) [ 1,2 ]. These sludges have a great amount of organic matter that must be stabilized before its final disposal [ 3 ]. Anaerobic digestion is widely applied for effective sludge stabilization and biogas production and it involves four steps: hydrolysis, acidogenesis, acetogenesis and methanogenesis [ 4 ].

The hydrolysis step (particulate organic matter conversion into soluble substances) and the methanogenesis step (conversion of acetic acid, $\mathrm{CO}_{2}, \mathrm{H}_{2}$, and others to methane) are believed to be the rate-limiting steps of anaerobic digestion [ 5,6 ]. 
Several physical and chemical methods have been applied as hydrolytic pre-treatments such as ultrasonication, alkaline hydrolysis, high pressure extruding, ozonization, enzymatic hydrolysis and thermal hydrolysis, and these pre-treatments have been applied individually or in combination[ 7-11 ]. Among them, thermal hydrolysis has proven to be a successful approach to making sewage sludge more amenable to anaerobic digestion and there are nearly 80 facilities either in operation or in planning around the world, with the first installation in 1995 [ 12 ]. The reported benefits of thermal hydrolysis are related to: increased digestion loading rate due to altered rheological properties, improved biodegradation of (especially activated) sludge, pathogen reduction and enhanced dewaterability [ 13,14 ]. Also, the energy input needed for the hydrolysis process is thermal energy and could be satisfied from the energy production of the process itself, resulting in an energetically self-sufficient process [ 15 ]. In spite of the advantages that thermal hydrolysis presents, it also has some disadvantages or limitations, being the main ones: investment costs are relatively high because several tank - reactors must be installed that operate at temperatures of $150-180^{\circ} \mathrm{C}$ and pressures of $0.37-0.95 \mathrm{MPa}$ [ 16-18 ]. These operational conditions demand extreme care by imposing on the treatment plant an important operational pressure. A constant threat for anaerobic digestion following the thermal hydrolysis process is related to the possible ammonium inhibition of the digestion process. Thermal hydrolysis allows an increase in loading rate due to altered rheology, increases the solubility of proteins, and improves the breakdown of those proteins [ 19 ], which causes an increase in ammonia and also in alkalinity, resulting in a rise in $\mathrm{pH}$. The increase in $\mathrm{pH}$ (and also temperature) shifts the equilibrium position away from ammonium to its free state. Having no charge, free ammonia diffuses easily into the cells and once 
there, it ionizes to form ammonium resulting in an intracellular $\mathrm{pH}$ imbalance, causing the inhibition of methanogenic archaea [ 20,21 ].

Biological hydrolysis has also been studied [ 22-24 ]. The biological process that has given better results is micro aerobic hydrolysis [ 25-27 ]. Lim and Wang [ 28 ] suggested that the added oxygen was consumed fully by facultative microorganisms and a reducing environment for organic matter degradation was maintained. Other than higher COD solubilization, micro-aeration pretreatment led to greater VFA accumulation and to the conversion of other short chain fatty acids to acetate. This could be due to the enhanced activities of hydrolytic and acidogenic bacteria and the degradation of slowly biodegradable compounds under microaerobic conditions. Recently, Montalvo et al. [ 29,30 ] found that by means of an air supply to mixed sewage sludge prior to anaerobic digestion the methane yield value increased by $114 \%$ with respect to that obtained with the non-aerated sludge. In the micro-aeration process carried out at an aeration level of $0.35 \mathrm{vvm}$, increases in soluble proteins and total sugar concentrations of $185 \%$ and $192 \%$ with respect to their initial values were found, respectively, after $48 \mathrm{~h}$ of aeration. At the above micro-aerobic conditions, soluble chemical oxygen demand $\left(\mathrm{COD}_{\mathrm{S}}\right)$ augmented $150 \%$, whereas the volatile suspended solids (VSS) content decreased to $40 \%$ of their initial respective values. For aeration times of $60 \mathrm{~h}$ the above-mentioned parameters did not vary significantly with respect to those observed at $48 \mathrm{~h}$.

Methanogenic archaea are microorganisms that carry out methane formation in anaerobic processes. It is a specialized group of obligate anaerobic microorganisms that decompose organic matter to form methane and for carrying out this biochemical reaction they require some heavy metals and cations as nutritional requirements [ 31,32 ]. It has also 
been found that the absence of these micronutrients has caused problems in anaerobic processes [ 33,34 ]. On the other hand, it has been proven that the use of metallic compounds improves anaerobic biodegradability and biogas production [ 35,36 ]. Zhang et al. [ 37 ] fed anaerobic reactors with a model trace element solution (Fe, B, Zn, Cu, Mn, $\mathrm{Mo}, \mathrm{Co}, \mathrm{Ni}, \mathrm{Se}$ ) and found a better performance in terms of higher and stable methane productivity, higher methane content, constant $\mathrm{pH}$ value, and relatively lower VFA level than reactors operated without a trace element solution. Kim et al. [ 38 ] observed that an efficient removal of propionate at high levels of VFA required supplementation of $\mathrm{Ca}, \mathrm{Fe}$, $\mathrm{Ni}$, and $\mathrm{Co}$ in a thermophilic non-mixed reactor.

In spite of these obvious advantages of the application of traces of metals to the anaerobic digestion, this procedure must be applied taking into account that trace element supplementation anaerobic digestion can both stimulate or inhibit the process depending, basically, on their concentrations [ 39,40 ]. Also, it must be taken into account that typically, trace metal-requirements have been reported with pure cultures with a simple substrate, such as acetate, hydrogen, or methanol. However, for more complex substrates and real wastewaters, trace nutrient requirements appear to have been satisfied empirically without the solid knowledge of minimum requirements [ 41 ].

The addition of solid wastes containing metals has been evaluated by some researchers using different residues such as municipal solid waste incinerator (MSWI) fly, refuse and nickel solid mining residues in the anaerobic digestion of the organic fraction of municipal solid waste and synthetic wastes obtaining very favourable results [ 42-45 ]. This alternative not only proves to be an interesting economic route from the point of view of the 
source of metals, but it is also a significant contribution to reducing the environmental liabilities that constitute the waste used as a source of metals giving a use value to them.

In combustion processes in thermal power plants, a large amount of fly-ash products (FAP) is generated. The FAP produced from power plants is taken to landfills or stored in ash lagoons [46]. These disposal strategies not only increase the burden on landfills, but they also have a significant impact on the surrounding habitats and ecosystems [47]. But fly ash has an important content in several metals which are necessary for methanogenic archaea [ 48 ]. Other solid residues that have several metals come from copper mining extraction. Due to their compositions, they are attractive for use as nutrient and trace metal suppliers in anaerobic digestion processes. Morever, given that they are wastes from the mining industry, they do not represent an additional cost for the process.

Thus, the aim of the present work, related to the biomass conversion into renewable energy, was to evaluate the influence of applying micro-aeration to improve the hydrolysis step of mixed sewage sludge and adding metals from solid residues such as fly ash or copper mining residues to enhace methanogenesis yield in the anaerobic digestion process of the mentioned sludge carried out at a mesophilic temperature. This is the first report that appears in the literature on the use of copper mining residues in the anaerobic digestion process and also is the first report showing the combination of the application of preaerobic hydrolysis with subsequent anaerobic digestion applying these residues.

\section{MATERIALS AND METHODS}

The study consisted of the realization of two experimental series (I and II). In the experimental series I, the behaviour of the micro-aeration in the hydrolysis of mixed sludge 
was evaluated by performing three experimental runs with different samples of these sludges to obtain representative results. All experimental runs were performed in duplicate. In the experimental series II, the behaviour of anaerobic digestion of sludge was evaluated using mixed sludge, with or without aerobic pretreatment and with or without solid residues containing traces of metals. In the series II, three experimental runs were also performed and each assay was carried out in duplicate.

\subsection{Raw materials}

The substrate for all the assays was a mixture of primary sludge $(60 \%)$ and secondary sludge (waste activated sludge, WAS) (40\%). This mixture is called mixed sludge and it comes from "La Farfana", a municipal wastewater treatment plant that is operated by Aguas Andinas, located in Santiago de Chile. The initial values of the Physico-chemical parameters of the reactors (inoculum + mixed sludge, IMS) are summarized in Table 1. The three different values included corresponded to different samples of mixed sludge.

The inoculum for anaerobic assays was obtained from a sludge anaerobic reactor operated in "La Farfana" and had a specific methanogenic activity of $0.34 \mathrm{~g} \mathrm{CH}_{4}-\mathrm{COD} \cdot \mathrm{g}$ $\mathrm{VSS}^{-1} \cdot \mathrm{L}^{-1}$; VSS of $95-105 \mathrm{~g} \cdot \mathrm{L}^{-1}$, and $\mathrm{pH}$ of 7.4. In the micro-aeration tests no inoculum was required since the mixed sludge contained aerobic microorganisms from the WAS.

The fly ash was obtained from a thermoelectric power plant located in the north of Chile. Ash was taken from electrostatic precipitators used to collect particulate matter generated in the combustion of bituminous coal in thermoelectric power plants, which are placed before the gaseous effluents leave the plant. Mining solid residues from copper 
extraction were obtained from a copper mining located in the north of Chile. Table 2 shows the main chemical characteristics of both solid residues.

Table 2 shows that the mining residues possess a greater amount of $\mathrm{Mn}, \mathrm{Mo}, \mathrm{Co}, \mathrm{Fe}$ and $\mathrm{Cu}$ compounds indicated in the literature as stimulants of the anaerobic process, in particular the latter, in relation to the ashes, due to the origin of the material [ 37 ]. However, the ashes contain more nickel and a good amount of iron. It should also be noted that the fly ashes are generated by a high temperature oxidation process, so the metals that are originally in the fuel are mainly converted into oxides that are poorly soluble compounds [ 48 ].

\subsection{Experimental design and set up.}

Figure 1 shows a scheme of the experiment flow chart.

The micro aerobic hydrolysis tests (Series I) were carried out in flasks of $900 \mathrm{~mL}$ of effective volume, where air was supplied by fish tank pumps through a hose that had a passage valve for regulating the air flow to 0.35 volume of air per reactor volume per minute (vvm) for 48 hours. The process temperature was kept at $35^{\circ} \mathrm{C}$ by temperatureregulated baths [ 29 ]. In each pretreatment air was injected continuously into the bioreactors by mini-compressors $(0-10 \mathrm{~L}$ per minute, $\mathrm{Lpm})$ and distributed by small diffusers placed almost at the bottom of each reactor. The air flow rate (AFR) was calibrated before the pretreatment assays using the volume variation method.

The performance of a micro-aerobic hydrolysis of mixed sludge and its influence as a pre-treatment of sludge for its subsequent anaerobic digestion was previously evaluated. 
Three experimental series were carried out to evaluate the optimum micro-aeration levels in the range from 0.1 to 0.5 air volume/min. reactor volume (vvm) and operation times within

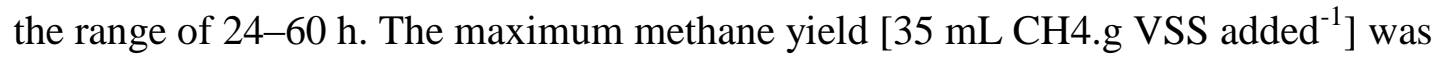
obtained for an aeration level of $0.35 \mathrm{vvm}$. In other study the effect of air flow rate (AFR), pre-treatment time, and temperature on a microaerobic pre-treatment were determined, including its effect on $\mathrm{CH}_{4}$ generation. For this, four AFR $(0.1,0.3,0.5$, and $1 \mathrm{vvm})$, three temperatures $\left(20,25\right.$ and $\left.35^{\circ} \mathrm{C}\right)$, and three aeration times $(24,48$ and $60 \mathrm{~h})$ were evaluated in 1-L and 5-L bioreactors. The effect on $\mathrm{CH}_{4}$ production was evaluated in $280-\mathrm{mL}$ bioreactors, using previously aerated sewage sludge. It was found that the micro-aerobic pre-treatment improves the hydrolytic process, with an increase of proteins, total sugars, soluble chemical oxygen demand (COD), and a greater removal of volatile suspended solids (VSS) compared to a system without aeration. It was determined that an $\mathrm{AFR}=0.3 \mathrm{vvm}, 48 \mathrm{~h}$ of aeration time, and a temperature of $35^{\circ} \mathrm{C}$ were the best operational conditions for increasing hydrolysis rate.

In the Series II glass reactors of $200 \mathrm{~mL}$ effective volume were used. Each reactor was filled with $40 \mathrm{~mL}$ of anaerobic inoculum and $160 \mathrm{~mL}$ of mixed sludge, which corresponded to $20 \%$ and $80 \%$ of the effective volume of the reactor, respectively.

The anaerobic digesters were sealed and the headspace was flushed with $\mathrm{N}_{2}$ at the beginning of the tests. The produced biogas was measured by liquid displacement after going through a $3 \%(w / w) \mathrm{NaOH}$ solution to capture the produced $\mathrm{CO}_{2}$; the remaining gas was assumed to be only methane [ 49,50 ]. The anaerobic tests were carried out for a period of approximately 20-25 days until the accumulated gas production remained essentially unchanged, i.e. on the last day production was lower than $3 \%$ of the accumulated methane 
produced. Due to the importance of maintaining homogeneity of the sludge within the reactors, they were subjected to a moderate manual stirring several times per day for several seconds. The anaerobic digester temperature was kept at $35 \pm 2{ }^{\circ} \mathrm{C}$ using automatically controlled aquarium heaters.

The concentrations of fly ash and copper mining residues used in the anaerobic assays were $250 \mathrm{mg} \cdot \mathrm{L}^{-1}$ and $25 \mathrm{mg} \mathrm{Cu} \cdot \mathrm{L}^{-1}$, respectively. In addition, a reactor without metal addition was also used as the control. An experimental run without aerobic pretreatment and without metal addition was also carried out as a blank assay.

A schematic diagram of the experimental design used is illustrated in Figure 2.

\subsection{Chemical and statistical analyses}

All chemical analyses were determined according to the Standard Methods of the American Public Health Association Standard Methods [ 51 ]. Specifically, COD and VSS were analysed according to the closed digestion and colourimetric method 5220D and 2540B standard methods, respectively. $\mathrm{pH}$ was determined using a Crison model 20 Basic $\mathrm{pH}$-meter. The evolution of parameters during the aerobic assays was monitored by samples taken from each reactor at different times, whereas parameter evolution during the anaerobic assays was carried using the following procedure: two or three times a week, two digesters working under the same conditions were taken out of operation and the values of all physical and chemical parameters were determined. The determination of metal concentrations was performed using a Perkin Elmer Optima 3000 ICP according to standard protokcols based on official methods of the US-EPA [ 52 ]. 
The statistic processing and analysis of data were carried out using the Minitab 8 software. An analysis of variance (ANOVA) was made, and a comparison of confidence intervals for mean values was made with a confidence level of $95 \%$.

As was previously mentioned in section 2.2, various experimental runs were performed either in experimental series I or II with the aim of assessing the influence of the sludge characteristics and their variations on the reactor behaviour and performance. However, considering that the results obtained in the different tests have variations of the order of 3 $5 \%$, in some cases only data corresponding to one experimental run will be shown, each one having been performed in duplicate. Each analysis was also performed, at least, in duplicate, which allows the statistical validation of these results.

\section{RESULTS AND DISCUSSION}

\subsection{Series I: Aerobic pretreatment (hydrolysis)}

Table 3 shows the main results obtained in the experimental Series I. Table 3 also shows the variation (increase or decrease) in different parameters during the micro-aerobic process (results from three assays with three different mixed sludge samples). It can be observed that VSS decreases while soluble organic matter $\left(\mathrm{COD}_{\mathrm{S}}\right)$ increases significantly. This significant increase in the soluble organic matter can be related to an increased solubility of this material, allowing to augment its content in simpler soluble compounds. The $\mathrm{pH}$ increase is mainly due to the increase in total ammonia between $170 \%$ and $350 \%$, as shown in Table 3. In this table are presented the results of three assays carried out with three different mixed sludge samples. As was mentioned previously it was convenient to submit to study three samples of sludge taken at different times in order to obtain more 
reliable results. From this table can be observed the range of values of the different parameters analyzed, both at the beginning and at the end of the micro aeration experiments as well as the percentages of increase or decrease of these values.

The dissolved oxygen concentration at the end of micro-aeration was zero in all the processes assayed.

As shown in Table 3, the values of $\mathrm{COD}_{\mathrm{S}}$, soluble protein and total sugars present a significant increase at the end of the aerobic pretreatment stage, indicating that microaeration improves the hydrolysis step, since it increases the solubility and the conversion of complex organic particles into simpler soluble compounds. Simultaneously, a degradation of the organic matter occurs and as expected a decrease in the VTS and VSS contents was achieved at the end of the process. The $\mathrm{pH}$ undergoes a slight increase during microaeration, which may be mainly due to the increase in the ammoniacal nitrogen caused by the rupture of the complex organic matter such as aminoacids and proteins.

\subsection{Series II: Anaerobic assays}

As was previously explained in this experimental series only the results corresponding to one of the three experimental runs carried out will be shown.

Figure 3 illustrates the $\mathrm{pH}$ evolution during the anaerobic processes.

This figure 3 shows a decrease in $\mathrm{pH}$ during the early days of the process, which is caused by the action of acidogenic bacteria [ 53 ]. After the first three days, a trend of increasing $\mathrm{pH}$ associated with protein hydrolysis can be seen which can be confirmed by the increase in ammonium nitrogen as shown in Table 4. Finally, pH stabilises between 6.6 
and 6.8, suitable values for a smooth trouble-free functioning of the process. Lim and Wang [ 28 ], who worked with previously aerated sludge, obtained very similar $\mathrm{pH}$ profiles to those found in this study. The $\mathrm{pH}$ profile obtained in the Lim and Wang [28] studies are very similar to those obtained in the present research. These authors found that, starting from $\mathrm{pH} 6.5$, it decreased to 5.7 on the third day of anaerobic digestion, something that also occurred in the present investigation, starting with the same $\mathrm{pH} 6.5$, and reaching a $\mathrm{pH}$ of 5.6 on the third day, with the $\mathrm{pH}$ risin from that day on, reaching $\mathrm{pH} 7.2$ at 17 days of digestion. However, Lim and Wang reached $\mathrm{pH} 7.2$ at 38 days of anaerobic digestion, and that may be due to the different characteristics of the substrates used in both studies, since these authors used co-digestion of brown water and food waste.

This means that despite the hydrolysis carried out by micro aeration, remaining materials are able to be hydrolysed during the early stages of the anaerobic process. After that, the $\mathrm{pH}$ may also rise because there are several acidophilic methanogenic Archaea such as Methanosarcina sp. which are favourable for consuming organic acids and preventing excessive $\mathrm{pH}$ decline [ 54 ]. There were no statistically significant differences in $\mathrm{pH}$ evolution between the different anaerobic processes operated. The ANOVA analysis showed that the Fcal $=$ Ftab so the hypothesis, with a significance level $p=0.05$, is approved, that none of the mean values of the different processes differ. A more detailed analysis was performed with tStudent tests for the contrast of two means, finding no condition showed statistically significant differences between them.

Table 4 shows the amounts of ammonium that are achieved at the end of anaerobic processes. As can be seen, none of them can be considered toxic or inhibitory concentrations for anaerobic processes as indicated above. 
Figure 4 shows the $\mathrm{COD}_{\mathrm{S}}$ evolution during the anaerobic processes. It can be seen how the $\mathrm{COD}_{\mathrm{S}}$ decreases with time, and in the early days this decrease is very small, a time period corresponding to the acclimatization stage. Final $\mathrm{COD}_{\mathrm{S}}$ removals in anaerobic processes were $58 \%, 68 \%$ and $69 \%$ for the control, copper mining residues and fly ash, respectively. There were no statistically significant differences between the results obtained for fly ash and mining residues.

Figure 5 shows how the volatile suspended solids (VSS) decreased with time, but from the $25^{\text {th }}$ day onwards there was virtually no change in the VSS concentration. This behaviour matches with that observed in Figure 6 regarding the production of methane, which also practically ceases around the $25^{\text {th }}$ day. VSS removals in the anaerobic processes were $38 \%, 59 \%$ and $61 \%$ for the control, copper mining residues and fly ash, respectively. There were no statistically significant differences between the results obtained for fly ash and mining residues.

Figure 6 shows the variation in the cumulative methane production $\left(\mathrm{mLCH}_{4} \cdot \mathrm{gVSS}\right.$ $\operatorname{added}^{-1}$ ) with digestion time. It can be seen that methane production increased by $50 \%$, $162 \%$ and $200 \%$ for the control, copper mining residues and fly ash, respectively, compared to the anaerobic digestion of the blank. Huiliñir et al. [ 48 ] also found an increase of $135 \%$ in methane production in the batch anaerobic digestion process for residual sludge from the paper industry water treatment when fly ash was added to the digesters as suppliers of trace metals. 
The significant increase in methane production when ash and mining waste were added to the digesters may be due to two factors: on the one hand, the inclusion of solids could contribute to an increase in the contact surface between microorganisms and substrate. However, given the high concentrations of suspended solids in the reactors this mechanism contributes little to the increase in process efficiency because much of these are inorganic suspended solids that tend to clog this contact surface. In some studies it has been shown that the addition of zeolites to the anaerobic digestion of piggery wastewaters (more diluted than mixed sludge) from certain doses has a negative influence on anaerobic digestion [ 55 ]. These authors found that up to $4 \mathrm{~g}$ of zeolite $\cdot \mathrm{L}^{-1}$ the anaerobic process was favoured, but for doses higher than $8 \mathrm{~g}$ of zeolite $\mathrm{L}^{-1}$ a significant reduction in methane production was observed. These researchers pointed out that the increase in total solid concentration also increases the apparent viscosity of the medium, thereby hindering mass transfer between the substrate and microorganisms responsible for the process, decelerating the anaerobiosis. In the same way, doses of $5 \mathrm{mg} \cdot \mathrm{L}^{-1}$ of mining residues from $\mathrm{Ni}$ extraction (Cola) that contain a certain amount of $\mathrm{Ni}, \mathrm{Fe}$ and $\mathrm{Co}$ allowed stimulating the batch anaerobic digestion of a synthetic substrate (composed of volatile fatty acids, VFA, and sucrose) increasing methane yield in relation to a control. By contrast, when the residue doses increased to $7 \mathrm{mg} \cdot \mathrm{L}^{-1}$ the methane production decreased [ 43 ]. On the other hand, the two residues studied in the present work (fly ash and mining residues) have several metals that can contribute to enhancing the anaerobic process and to increasing methane production. While it is true that individual metal concentrations used in this study appear to be only stimulants for copper mining waste (according to Table 2) it is also known that combining several metals even at concentrations lower than those reported as stimulants 
may enhance anaerobic digestion [ 54,56 ]. Another contribution that can be important to the increase in methane production is the presence of alkaline substances in anaerobic digestion processes. Lo [ 43 ] showed that the released alkali metals contained in bottom ashes from municipal solid waste seemed to exert a beneficial effect on anaerobic digesters within which the volatile acids were buffered by the increase in compounds with neutralizing capacity.

\subsection{Metals in sludge digested}

The Chilean law, and more specifically Article 24 of Presidential Decrete $\mathrm{N}^{\mathrm{o}} 4$ for handling sludge from sewage treatment plants establishes maximum concentrations for metals in sludge applied to agricultural soils (Class A) and degraded soils (Class B) [57]. Table 5 shows comparative metal values among digested sludge produced in anaerobic reactors and maximun values allowed for sludge Class A and B.

It should be noted that some elements such as $\mathrm{Cd}$ and $\mathrm{Pb}$ that do not initially appear in the fly ashes are detected, in extremely small amounts, in the sludge generated in the anaerobic process where the ash was added which may be due to the fact that in mixed sludge and in the sludge used as inoculum there would be a small amount of these chemical species

The digested sludge that had higher metal amounts was that derived from the digesters where copper mining residues were applied, the metal concentrations $\left(\mathrm{mg}^{\mathrm{kg}} \mathrm{kg}^{-1}\right)$ being the following ones: As (2.4); Cd (1.2); $\mathrm{Cu}$ (249); $\mathrm{Ni}$ (9.8); $\mathrm{Pb}$ (14); $\mathrm{Zn}$ (484). The requirements 
for Class A sludge are the most strict, with the maximum permitted concentration (mg. $\left.\mathrm{kg}^{-1}\right)$ of metals in sludge being as follows: As (20); $\mathrm{Cd}(1.2) ; \mathrm{Cu}(8) ; \mathrm{Ni}(80) ; \mathrm{Pb}(300) ; \mathrm{Zn}$ (2000). As can be seen the metal concentration in digested sludge is well below than allowable values by law to use sludge digested as fertilizer.

The use of traces of metals in the anaerobic digestion of residues has been treated to some extent in the literature and the positive influence of these, up to certain levels, on the production of methane has been fully demonstrated [ 58 ]. Two aspects must be considered in order to determine the real causes of the effectiveness of the metals on the anaerobic digestion, one is related to the individual effect of the different metals or the combined effect of these ones [ 59 ] and the other aspect are related with bioavilability of the metals [ 60 ]. On the other hand the improvement of the anaerobic processes has also been observed when certain solids have been added inside the digesters increasing the contact between the microorganisms and the substrates, acting as a kind of biocatalysts [ 61 ] or these solids have served as a support medium to immobilize microorganisms and form biofilms with high concentration of biomass and increase the rate of degradation of organic matter with the consequent increase of methane production in digesters [ 62 ]. These physical - biological phenomenon will depend on the characteristics of the surface of the materials added to the anaerobic process. In the case of the fly ashes and the mining residues used in this investigation there are different studies where it is shown that these materials can have rough surfaces or not depending on the material of origin or the deposit from where they come [ 63,64 ]. The characteristics of the crystalline and amorphous phases in fly ash vary with the operating conditions of the thermal power plant and the types of fuels used. Therefore, it is presumed that these phenomena could be occurring in 
the anaerobic processes developed in the present study, however, it is very convenient to make in-depth studies about those aspects

As previously mentioned, the process applied on an industrial scale to improve the hydrolysis of sludge is thermal, and its limitations or disadvantages have been commented, being the aerobic process much simpler it will be possible in the near future to design and implement it at a real scale.

\section{CONCLUSIONS}

It was convincingly shown that the application of a small amount of air (microaeration) significantly improved the hydrolysis of mixed sewage sludge obtaining a process

effluent with suitable characteristics for anaerobic digestion $\left(35^{\circ} \mathrm{C}, 0 \mathrm{mg} \cdot \mathrm{L}^{-1}\right.$ of dissolved oxygen and $\mathrm{pH}$ increased). The addition of fly ash or mining waste significantly enhanced the anaerobic digestion of the sludge, thus increasing methane production by more than $100 \%$. A combination of micro aerobic hydrolysis with anaerobic processes carried out with the addition of trace metals from these residues increased methane production by 162\%-200\%. The digestates obtained after the anaerobic digestion of microaerated sludge with the above metal residues contain minimum metal concentrations that allow its use as fertilizer in agricultural soils.

\section{ACKNOWLEGMENTS}

The authors acknowledge the financial support provided by Universidad de Santiago de Chile, USACH under Project DICYT 091711MM.

\section{REFERENCES}


[ 1 ] H. Ma, X. Chen, H. Liu, B. Fu, Improved volatile fatty acids anaerobic production from waste activated sludge by $\mathrm{pH}$ regulation: Alkaline or neutral $\mathrm{pH}$ ?, Waste Management 48 (2016) 397-403.

[ 2 ] G. Zhang, Z. Wu, F. Cheng, Z. Min, D-J. Lee, Thermophilic digestion of wasteactivated sludge coupled with solar pond, Renewable Energy 98 (2016) 142-147.

[ 3 ] H.R. Sadabad, G.B. Gholikandi, G.B., Harvesting direct electricity from municipal waste-activated sludge simultaneous with its aerobic stabilization process: Investigation and optimization, Journal of Environmental Chemical Engineering 5 (2017)1174-1185.

[ 4 ] S. Kavitha,C. Jayashree, S.A. Kumar, I.T. Yeom, J.R. Banu, The enhancement of anaerobic biodegradability of waste activated sludge by surfactant mediated biological pretreatment, Bioresource Technology 168 (2014) 159-166.

[ 5 ] E. Lee, J. Cumberbatch, M. Wang, Q. Zhang, Kinetic parameter estimation model for anaerobic co-digestion of waste activated sludge and microalgae, Bioresource Technology 228 (2017) 9-17.

[ 6 ] K. Luo, Q.I. Yang, J. Yu, X. Li, G.J. Yang, B.X. Xie, Combined effect of sodium dodecyl sulfate and enzyme on waste activated sludge hydrolysis and acidification, Bioresource Technology 102 (2011) 7103-7110.

[ 7 ] N. Pérez-Rodríguez, D. García-Bernet, J.M. Domínguez, Extrusion and enzymatic hydrolysis as pretreatments on corn cob for biogas production, Renewable Energy 107 (2017) 597-603.

[ 8 ] Y. Li, Y. Jin, Y.J. Li, J.Y. Nie, Enhanced nitrogen distribution and biomethanation of kitchen waste by thermal pre-treatment, Renewable Energy 89 (2016) 380-388. 
[ 9 ] M. Mischopoulou, P. Naidis, S. Kalamaras, T.A. Kotsopoulos, P. Samaras, Effect of ultrasonic and andozonizationpretreatment on methane production potential of raw molasses wastewater, Renewable Energy 96 (2016) 1078-1085.

[ 10 ] Y. Yao, Y. Huang, F. Hong, The Influence of Sludge Concentration on its Thermophilic Anaerobic Digestion Performance Based on Low Temperature Thermal Hydrolysis Pretreatment, Procedia Environmental Sciences 31 (2016) 144-152.

[ 11 ] Y. Zhang, Ch. Zhang, X. Zhang, L. Feng, Y. Li, Q. Zhou, Waste activated sludge hydrolysis and acidification: A comparison between sodium hydroxide and steel slag addition, Journal of Environmental Sciences 48 (2016) 200-208.

[ 12 ] W.P.F. Barber, Thermal hydrolysis for sewage treatment: A critical review, Water Research 104 (2016) 53-71.

[ 13 ] R. Cano, A. Nielfa, M. Fdz-Polanco, Thermal hydrolysis integration in the anaerobic digestion process of different solid wastes: Energy and economic feasibility study, Bioresource Technology 168 (2014) 14-22.

[ 14 ] I. Sapkaite, E. Barrado, F. Fdz-Polanco, S.I. Pérez-Elvira, Optimization of a thermal hydrolysis process for sludge pre-treatment, Journal of Environmental Management 192 (2017) 25-30.

[ 15 ] S.I. Pérez-Elvira, F. Fdez-Polanco, M. Fdez-Polanco, P. Rodriguez, P. Rouge, Hydrothermal multivariable approach. Full-scale feasibility study, Electronic Journal of Biotechnology 11 (2008) 4.

[ 16 ] W. Qiao, X. Yan, J. Ye, Y. Sun, W. Wang, Z. Zhang, Evaluation of biogas production from different biomass wastes with/without hydrothermal pretreatment, Renewable Energy 36 (2011) 3313-3318. 
[ 17 ] D.L. Armstrong, C.P. Rice, M. Ramirez, M.A. Torrents, Influence of thermal hydrolisis of thermal hydrolysis-anaerobic digestion treatment of wastewater solids on concentrations of triclosan, triclocarban, and their transformation products in biosolids, Chemosphere 171 (2017) 609-616.

[ 18 ] O. Suárez-Iglesias, J.L. Urrea, P. Oulego, S. Collado, M. Díaz, Valuable compounds from sewage sludge by thermal hydrolysis and wet oxidation. A review. Science of The Total Environment, In Press, (2017).

[ 19 ] C. Bougrier, C. Albasi, J.P. Delgenes, H. Carrere, Effect of ultrasonic, thermal and ozone pre-treatments on waste activated sludge solubilisation and anaerobic biodegradability. Chemical Engineeringand Processing: Process Intensification, 45 (2006) 711-718.

[ 20 ] O. Yenigun, B. Demirel, Ammonia inhibition in anaerobic digestion: a review, Process Biochemistry 48 (2013) 901-911.

[ 21 ] J. Ariunbaatar, E. Scotto Di Perta, A. Panico, L. Frunzo, G. Esposito, P-N.L. Lens, F. Pirozzi, Effect of ammoniacal nitrogen on one-stage and two-stage anaerobic digestion of food waste, Waste Management 38 (2015) 388-398.

[ 22 ] S.F. Fu, S. He, X.S. Shi, N.R. Katukuro, M. Dai, R.B. Guo, The chemical properties and microbial community characterization on the thermohilic microaerobic pretreatment process, BioresourceTechnology 198 (2015) 372-379.

[ 23 ] J.Y. Liu, Y.M. Song, Y.H. Liu, R. Ruan, Fungal pretreatment of effluent from piggery anaerobic digestion of waste activated sludge enchanced by alpha-amylose, Biochemical Engineering Journal 62 (2015) 17-21. 
[ 24 ] M. Mutschlechner, P. Illmer, A.O. Wagner, Biological pretreatment: enhancing biogás production using the highly cellulolytic fungus Trichoderma viride, Waste Management 43 (2015) 98-107.

[ 25 ] P. Johansen, R. Bakke, Enhancing hydrolysis with microaeration, Water Science and Technology 53 (2006) 43-50.

[ 26 ] W. Charles, L. Walker, R. Cord-Ruwisch, Effect of pre-aeration and inoculum on the start-up of batch thermophilic anaerobic digestion of municipal solid waste, Bioresource Technology 100 (2009) 2329-2335.

[ 27 ] S.Y. Xu, A. Selvam, J.W.C. Wong, Optimization of microaeration intensity in acidogenicreactor of a two-phase anaerobic digester treating food waste, Waste Management 34 (2014) 363-369.

[ 28 ] J.W. Lim, J-Y. Wang, Enhanced hydrolysis and methane yield by applying microaeration pretreatment to the anaerobic co-digestion of brown water and food waste, Waste Management 33 (2012) 813-819.

[ 29 ] S. Montalvo, F. Ojeda, C. Huiliñir, L. Guerrero, R.Borja, A. Castillo, Performance evaluation of micro-aerobic hydrolysis of mixed sludge: Optimum aeration and effect on its biochemical methane potential, Journal of Environmental Science and Health - Part A 51 (2016) 1269-1277.

[ 30 ] S. Montalvo, C. Huiliñir, F. Ojeda, A. Castillo, L. Lillo, L. Guerrero, Microaerobic pretreatment of sewage sludge: Effect of air flow rate, pretreatment time and temperature on the aerobic process and methane generation, International Biodeterioration and Biodegradation 110 (2016) 1-7. 
[ 31 ] N. Ács, E. Kovács, R. Wirth, Z. Bagi, O. Strang, Z. Herbel, G. Rákhely, K.L. Kovács, Changes in the Archaea microbial community when the biogas fermenters are fed with protein-rich substrates, Bioresource Technology 131 (2013) 121-127.

[ 32 ] K. Bernat, M. Zielińska, A. Cydzik-Kwiatkowska, I. Wojnowska-Baryła, Biogas production from different size fractions separated from solid waste and the accompanying changes in the community structure of methanogenic Archaea, Biochemical Engineering Journal 100 (2015) 30-40.

[ 33 ] Z. Milán, S. Montalvo, N. Ruíz-Tagle, H. Urrutia, R. Chamy, E. Sánchez, R. Borja, Influence of heavy metal supplementation on specific methanogenic activity and microbial communities detected in batch anaerobic digesters, Journal of Environmental Science and Health Part A45 (2010) 1-8.

[ 34 ] C. Park, A. Bega, C. Unlu, R.A. Chadderton, W.R. McKean, P.M. Kohl, J.A. Hunt, J. Keaney, J.L. Willis, M. Duran, Acetoclastic methanogens in an anaerobic digester could be susceptible to trace metal supplementation, Water Science and Technology 62 (2010) 29052911.

[ 35 ] A. Mudhoo, S. Kumar, Effects of heavy metals as stress factors on anaerobic digestion processes and biogas production from biomass, International Journal of Environmental Science and Technology 10 (2013)1383-1398.

[ 36 ] H.M. Lo, H.Y. Chiu, S.W. Lo, F.C. Lo, Effects of micro-nano and non micro-nano MSWI ashes addition on MSW anaerobic digestion, Bioresource Technology 114 (2012) $90-94$.

[ 37 ] L. Zhang, W. Ouyang, A. Li, L. Zhang, Essential role of trace elements in continuous anaerobic digestion of food waste, Procedia Environmental Sciences 16 (2012) 102-111. 
[ 38 ] M. Kim, Y.H. Ahn, R.E. Speece, Comparative process stability and efficiency of anaerobic digestion: mesophilic versus thermophilic, Water Research 36 (2002) 43694385.

[ 39 ] Y. Chen, J.J. Cheng, K.S. Creamer, Inhibition of anaerobic digestion process: A review, Bioresource Technology 99 (2008) 4044-4064.

[ 40 ] Z.B. Yue, H.Q. Yu, Z.L. Wang, Anaerobic digestion of cattail with rumen culture in the presence of heavy metals, Bioresource Technology 98 (2007) 781-786.

[ 41 ] M. Takashima, K. Shimada, R.E. Speece, Minimum Requirements for Trace Metals (Iron, Nickel, Cobalt, and Zinc) in Thermophilic and Mesophilic Methane Fermentation from Glucose, Water Environment Research 83 (2011) 339-346.

[ 42 ] H.M. Lo, Metals behaviors of MSWI bottom ash co-digested anaerobically with MSW, Resources Conservation and Recycling 43 (2005) 263-280.

[ 43 ] I. Pereda, R. Irusta, S. Montalvo, J.L. del Valle, Solid mining residues from Ni extraction applied as nutrients supplier to anaerobic process: Optimal dose approach through Taguchi's methodology, Water Science and Technology 54 (2006) 209-219.

[ 44 ] H.M. Lo, M.H. Liu, T.Y. Pai, W.F. Liu, C.Y. Lin, S.C. Wang, C.J. Banks, C.H. Hung, C.F. Chiang, K.C. Lin, P.H. Chen, J.K. Chen, H.Y. Chiu, M.H. Su, T.A. Kurniawan, K.C. Wu, C.Y. Hsieh, H.S. Hsu, Biostabilization assessment of MSW co-disposed with MSWI fly ash in anaerobic bioreactors, Journal of Hazardous Materials 162 (2009) 12331242.

[ 45 ] R.J. Haynes, Reclamation and revegetation of fly ash disposal sites - challenges and research needs, Journal of Environmental Management 90 (2009) 43-53. 
[ 46 ] X.F. Lou, J. Nair, The impact of landfilling and composting on greenhouse gas emissions - a review, Bioresource Technology 100 (2009) 3792-3798.

[ 48 ] C. Huiliñir, S. Montalvo, L. Guerrero, Biodegradability and methane production from secondary paper and pulp sludge: Effect of fly ash and modeling, Water Science and Technology 72 (2015) 230-237.

[ 49 ] V. Córdoba, M.B. Colavolpe, M. Fernández, E. Santalla, E. Albertó, Potential methane production of spent sawdust used in the cultivation of Gymnopilus pampeanus, Journal of Environmental Chemical Engineering 4 (2016) 4418-4425.

[ 50 ] F. Suanona, F.Q. Suna, M. Li, X. Cai, Y. Zhanga, Y. Yana, Ch-P. Yua, Application of nanoscale zero valent iron and iron powder during sludge anaerobic digestion: Impact on methane yield and pharmaceutical and personal care products degradation, Journal of Hazardous Materials 321 (2017) 47-53.

[ 51 ] APHA, AWWA, WPCF, Standard Methods for the Examination of Water and Wastewater 22th ed. AWWA, Washington, D.C., 2012.

[ 52 ] I. Cortés, S. Montalvo, Evaluation of potential methane generation in the investigation of an abandoned contaminated landfill in Santiago, Chile, Brazilian Journal of Chemical Engineering 34 (2016) 723-731.

[ 53 ] S.V. Mohan, G. Mohanakrishna, P.N. Sarma, Integration of acidogenic and methanogenic processes for simultaneous production of biohydrogen and methane from wastewater treatment, International Journal of Hydrogen Energy 33 (2008) 2156-2166.

[ 54 ] J. Zhang, Y. Zhang, X. Quan, Sh. Chen, Enhancement of anaerobic acidogenesis by integrating an electrochemical system into an acidogenic reactor: Effect of hydraulic 
retention times (HRT) and role of bacteria and acidophilic methanogenic Archaea, Bioresource Technology 179 (2015) 43-49.

[ 55 ] Z. Milán, E. Sánchez, P. Weiland, R. Borja, A. Martín, K. Ilangovan, Influence of different natural zeolite concentrations on the anaerobic digestion of piggery waste, Bioresource Technology 80 (2001) 37-43.

[ 56 ] J. Moestedt, E. Nordell, S. Shakeri Yekta, J. Lundgren, M. Martí, C. Sundberg, J. Ejlertsson, B. Svensson, H. Björn, Effects of trace element addition on process stability during anaerobic co-digestion of OFMSW and slaughterhouse waste, Waste Management 47 (2016) 11-20.

[ 57 ] MINISTERIO SECRETARÍA GENERAL DE LA PRESIDENCIA, República de Chile, 2009. Decreto Supremo \#4 para el manejo de lodos generados en plantas de tratamiento de aguas servidas.

[ 58 ] P. Jha, S. Schmidt, Reappraisal of chemical interference in anaerobic digestion processes, Renewable and Sustainable Energy Reviews 75 (2017) 954-971

[ 59 ] Y. Cai, B. Hua, L. Gao, Y. Hu, X. Wang, Effects of adding trace elements on rice Straw anaerobic mono-digestion: focus on changes in microbial communities using highthroughput sequencing, Bioresource Technology 239 (2017) 454-463.

[ 60 ] P. M. Thanh, B. Ketheesan, Zh. Yan, D. Stuckey, Trace metal speciation and biovailability in anaerobic digestion: A review, Biotechnology Advances 34 (2016) 122136.

[ 61 ] S. Montalvo, L. Guerrero, R. Borja, E. Sánchez, M.A. de la Rubia, Application of natural zeolites in anaerobic digestion processes: a review, Applied Clay Science 58 (2012) 125-133. 
[ 62 ] N. Fernández, S. Montalvo, F. Fernández-Polanco, L. Guerrero, I. Cortés, R. Borja, E. Sánchez, L. Travieso, Real evidence about zeolite as microorganism immobilizer in anaerobic fluidized bed reactors, Process Biochemistry 42 (2007) 721-728.

[ 63 ] D. Bondar, E. Coakley, Use of gypsum and CKD to enhance early age strength of high volume fly ash (HVFA) pastes, Construction and Building Materials 71 (2014) 93108.

[ 64 ] G.D. Moon, S. Oh, Y. Ch. Choi, Effects of the physicochemical properties of fly ash on the compressive strength of high-volume fly ash mortar, Construction and Building Materials, 124 (2016) 1072-1080.

\section{Figure captions}

Figure 1. Experimental flow chart

Figure 2. Schematic diagram of the experimental design used.

Figure 3. Evolution of $\mathrm{pH}$ during the anaerobic processes.

Figure 4. Evolution of CODS during the anaerobic processes.

Figure 5. Variation in the VSS content with time during the anaerobic processes.

Figure 6. Variation in cumulative methane production (mL CH4.g VSS-1) with digestion time (days). 
Table 1

Table 1. Initial mean values of physico-chemical parameters of reactors.

\begin{tabular}{|c|c|c|c|c|c|c|}
\hline \multicolumn{7}{|c|}{ Parameters } \\
\hline IMS & $\begin{array}{c}\mathrm{VTS}^{\mathrm{a}} \\
\left(\mathrm{mg} \cdot \mathrm{L}^{-1}\right)\end{array}$ & $\begin{array}{c}\mathrm{VSS}^{\mathrm{b}} \\
\left(\mathrm{mg} \cdot \mathrm{L}^{-1}\right)\end{array}$ & $\mathrm{COD}_{\mathrm{T}}^{\mathrm{c}}\left(\mathrm{mg} \cdot \mathrm{L}^{-1}\right)$ & $\mathrm{COD}_{\mathrm{S}}^{\mathrm{d}}\left(\mathrm{mg} \cdot \mathrm{L}^{-1}\right)$ & $\mathrm{pH}$ & $\mathrm{TAN}^{\mathrm{e}}\left(\mathrm{mg} \cdot \mathrm{L}^{-1}\right)$ \\
\hline 1 & 34000 & 31000 & 39700 & 7600 & 6.04 & 232 \\
\hline 2 & 32100 & 32100 & 39200 & 8000 & 6.03 & 129 \\
\hline 3 & 35300 & 32600 & 40200 & 7200 & 6.05 & 237 \\
\hline
\end{tabular}

${ }^{\mathrm{a}}$ Volatile total solids; ${ }^{\mathrm{b}}$ Volatile suspended solids; ${ }^{\mathrm{c}}$ Total Chemical Oxygen Demand;

${ }^{\mathrm{d}}$ Soluble Chemical Oxygen Demand; ${ }^{\mathrm{T}}$ Total ammonia nitrogen 
Table 2

Table 2. Metal composition of the solid residues used as trace metal suppliers.

\begin{tabular}{|c|c|c|}
\hline Element & Fly ash $\left(\mathrm{mg.kg}^{-1}\right)$ & Mining residues $\left(\mathrm{mg} \cdot \mathrm{kg}^{-1}\right)$ \\
\hline Cd & $<\mathrm{DL}$ & $2.38 \pm 0.2$ \\
\hline Zn & $5.40 \pm 0.5$ & $19.09 \pm 2.4$ \\
\hline $\mathrm{Cr}$ & $2.92 \pm 0.3$ & $1.94 \pm 0.3$ \\
\hline As & $<\mathrm{DL}$ & $1.89 \pm 0.2$ \\
\hline $\mathbf{C u}$ & $2.21 \pm 0.2$ & $2321.14 \pm 198$ \\
\hline $\mathbf{N i}$ & $6.17 \pm 0.4$ & $3.43 \pm 0.3$ \\
\hline $\mathbf{P b}$ & $<\mathrm{DL}$ & $11.86 \pm 1.4$ \\
\hline Al & $1315.42 \pm 112$ & $1678.16 \pm 120$ \\
\hline Se & $<\mathrm{DL}$ & $<\mathrm{DL}$ \\
\hline Mn & $21.05 \pm 2.0$ & $66.10 \pm 5.9$ \\
\hline Ag & $<\mathrm{DL}$ & $<\mathrm{DL}$ \\
\hline $\mathbf{V}$ & $13.36 \pm 0.9$ & $3.95 \pm 0.4$ \\
\hline $\mathbf{B a}$ & $44.36 \pm 3.8$ & $4.52 \pm 0.3$ \\
\hline Co & $<\mathrm{DL}$ & $6.35 \pm 0.5$ \\
\hline Mo & $<\mathrm{DL}$ & $11.67 \pm 0.9$ \\
\hline $\mathbf{B e}$ & $<\mathrm{DL}$ & $<\mathrm{DL}$ \\
\hline $\mathbf{B}$ & $35.03 \pm 2.9$ & $100.42 \pm 12$ \\
\hline $\mathbf{F e}$ & $3083.58 \pm 287$ & $17421.06 \pm 1812$ \\
\hline
\end{tabular}

DL: Detection Limit 
Table 3

Table 3. Variation in different parameters during the micro-aerobic processes*.

\begin{tabular}{|l|c|c|c|}
\hline Parameters & Initial values & Final values (48 hours) & $\begin{array}{c}\text { Increase }(+) \text { or } \\
\text { decrease }(-)(\%)\end{array}$ \\
\hline VTS $\left(\mathrm{mg} \cdot \mathrm{L}^{-1}\right)$ & $35300-32100 \pm 1200$ & $28593-26001 \pm 750$ & $19(-) \pm 2$ \\
\hline VSS $\left(\mathrm{mg} \cdot \mathrm{L}^{-1}\right)$ & $32600-31000 \pm 1000$ & $26406-25110 \pm 680$ & $29(-) \pm 3$ \\
\hline $\mathrm{COD}_{\mathrm{S}}\left(\mathrm{mg} \cdot \mathrm{L}^{-1}\right)$ & $8000-7600 \pm 700$ & $13200-13800 \pm 900$ & $78(+) \pm 2$ \\
\hline $\begin{array}{l}\text { Soluble protein } \\
\left(\mu \mathrm{g} \mathrm{BSA} \cdot \mathrm{L}^{-1}\right)\end{array}$ & $0.4-1.8 \pm 0.2$ & $2.5-4.0 \pm 0.2$ & $525(+) \pm 50$ \\
\hline $\begin{array}{l}\text { Total sugars } \\
\left(\mu \mathrm{g} \text { Glucose } \cdot \mathrm{L}^{-1}\right)\end{array}$ & $180-200 \pm 85$ & $500-600 \pm 100$ & $200(+) \pm 21$ \\
\hline TAN $\left(\mathrm{mg} \cdot \mathrm{L}^{-1}\right)$ & $129-237 \pm 56$ & $580-640 \pm 100$ & $170(+) \pm 15$ \\
\hline pH & $6.03-6.05 \pm 0.02$ & $6.20 \pm 0.05$ & $2(+) \pm 0.3$ \\
\hline
\end{tabular}

${ }^{\mathrm{a}}$ Bovine Serum Albumin. 
Table 4

Table 4. Initial and final ammonium nitrogen concentrations $\left(\mathrm{mg} \cdot \mathrm{L}^{-1}\right)$ in anaerobic reactors.

\begin{tabular}{|c|c|c|c|}
\hline & Influent & Effluent & Increase $(\%)$ \\
\hline Control & $639 \pm 0$ & $2175 \pm 71$ & 240 \\
\hline Mining residues & $639 \pm 0$ & $2407 \pm 311$ & 277 \\
\hline Fly ash & $639 \pm 0$ & $2356 \pm 61$ & 269 \\
\hline
\end{tabular}




\section{Table 5}

Table 5. Comparative mean values (mg. $\mathrm{kg}^{-1}$ ) among digested sludge produced in anaerobic reactors and maximun values allowed for sludge Class A and B.

\begin{tabular}{|c|c|c|c|c|c|c|}
\hline Sludge & As & $\mathbf{C d}$ & $\mathbf{C u}$ & $\mathbf{N i}$ & $\mathbf{P b}$ & $\mathbf{Z n}$ \\
\hline $\begin{array}{c}\text { With Fly } \\
\text { Ash }\end{array}$ & $2.6 \pm 0.3$ & $1.14 \pm 0.1$ & $156.98 \pm 17$ & $9.05 \pm 0.8$ & $12.75 \pm 0.9$ & $455.22 \pm 48$ \\
\hline $\begin{array}{c}\text { With Mining } \\
\text { Residues }\end{array}$ & $2.36 \pm 0.3$ & $1.23 \pm 0.1$ & $248.85 \pm 20$ & $9.79 \pm 0.7$ & $13.98 \pm 1.4$ & $484.19 \pm 52$ \\
\hline Class A & 20 & 8 & 1000 & 80 & 300 & 2000 \\
\hline Class B & 40 & 40 & 1200 & 420 & 400 & 2800 \\
\hline
\end{tabular}


Figure 1

Pretreatment

\begin{tabular}{|c|c|c|c|}
\hline Aeration 0.35 vvm & Time 48 hours & Temperature $35^{\circ} \mathrm{C}$ & $900 \mathrm{ml}$ reactors \\
\hline
\end{tabular}

\begin{tabular}{|l|l|l|l|}
\hline Solid residues addition & Time 30 Days & Temperature $35^{\circ} \mathrm{C}$ & $250 \mathrm{ml}$ reactors
\end{tabular} 
Figure 2
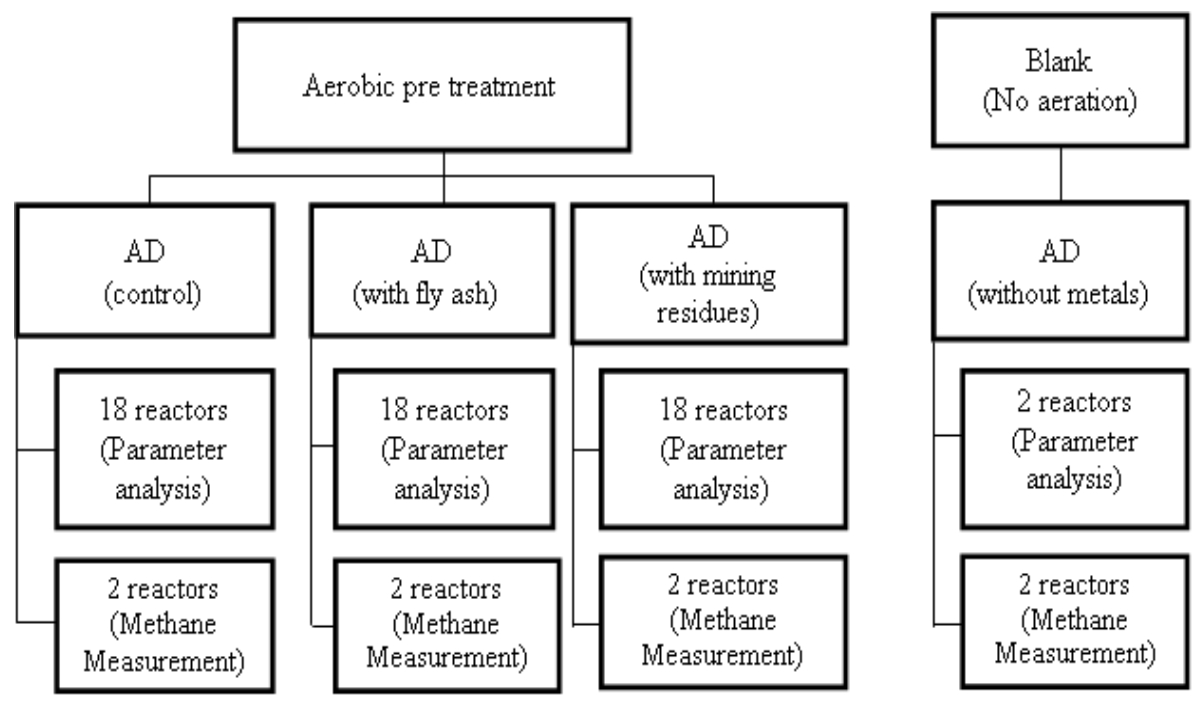
Figure 3

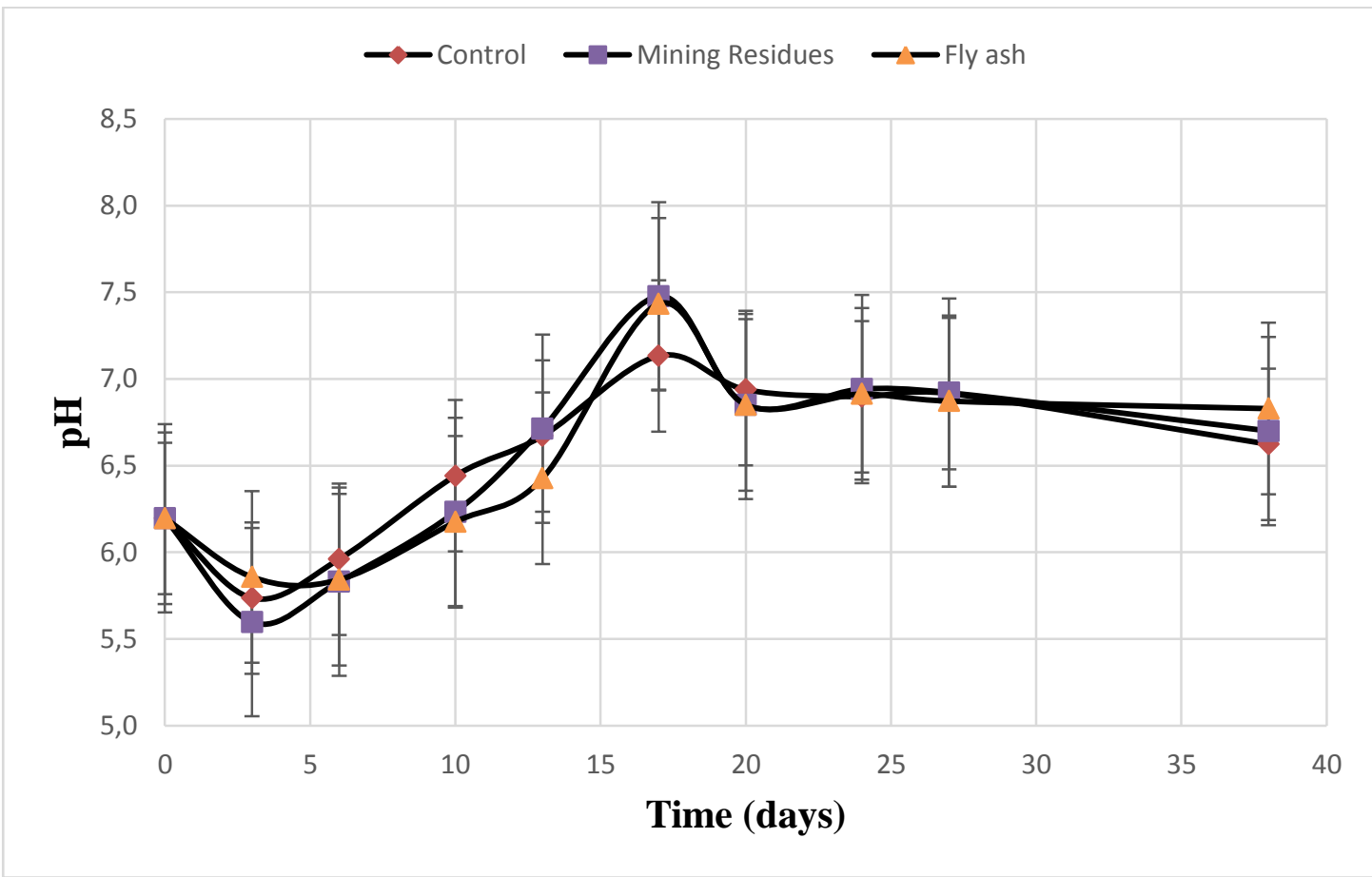


Figure 4

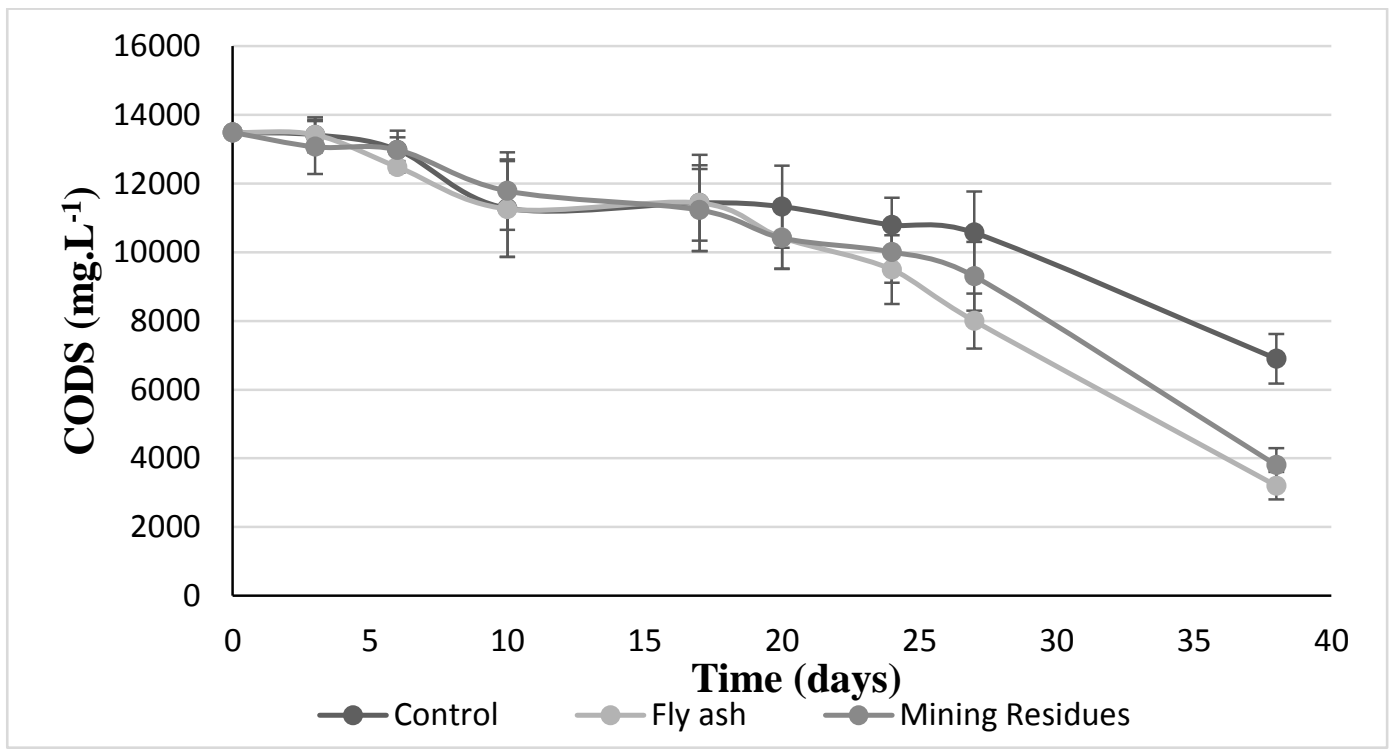


Figure 5

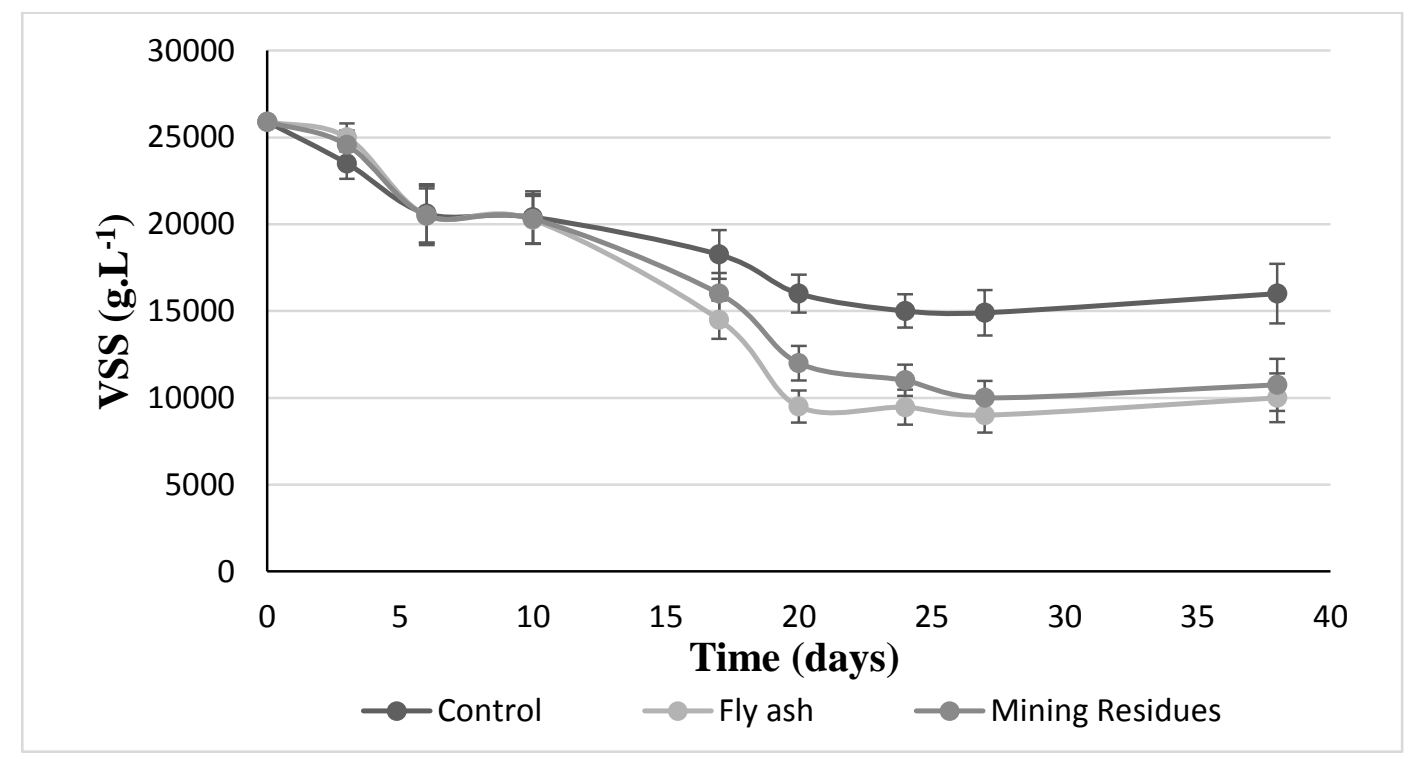


Figure 6

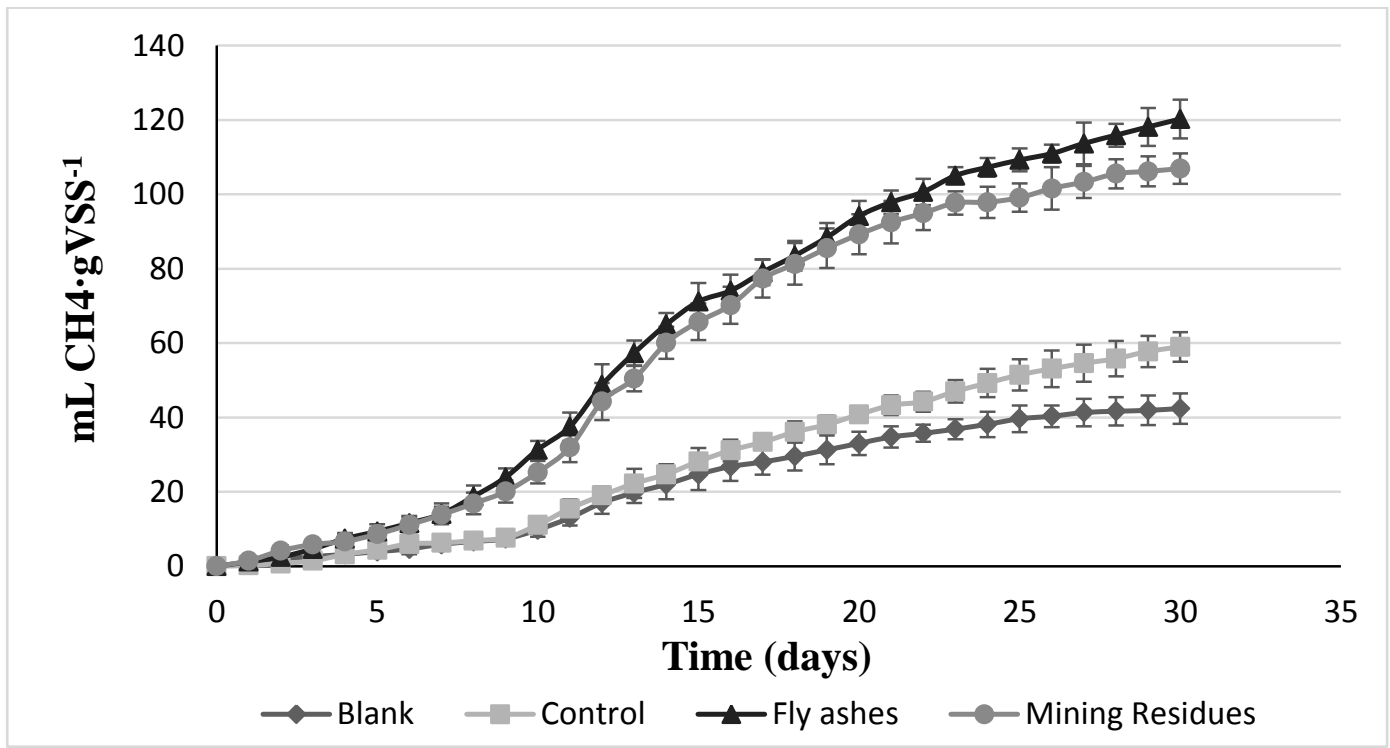

